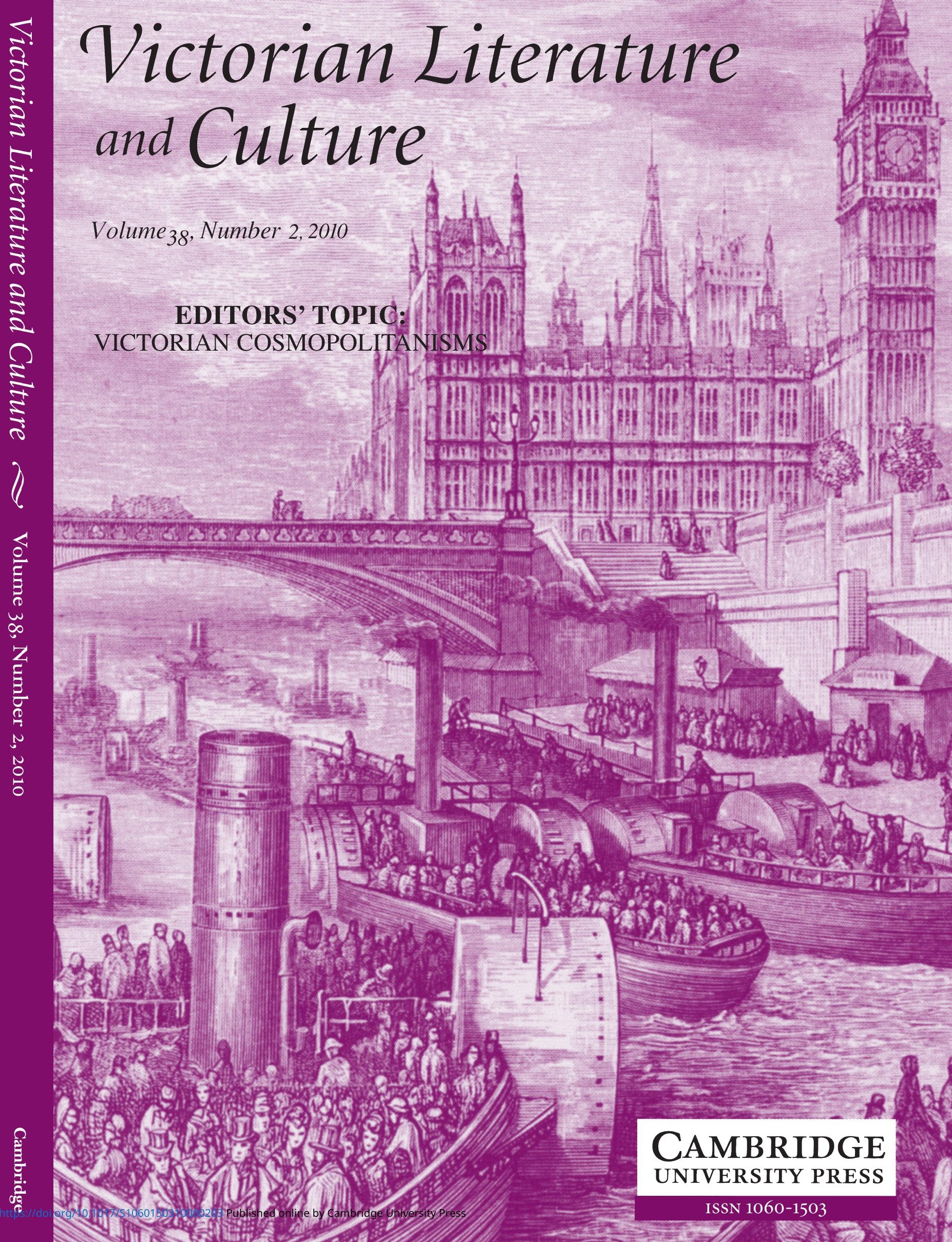




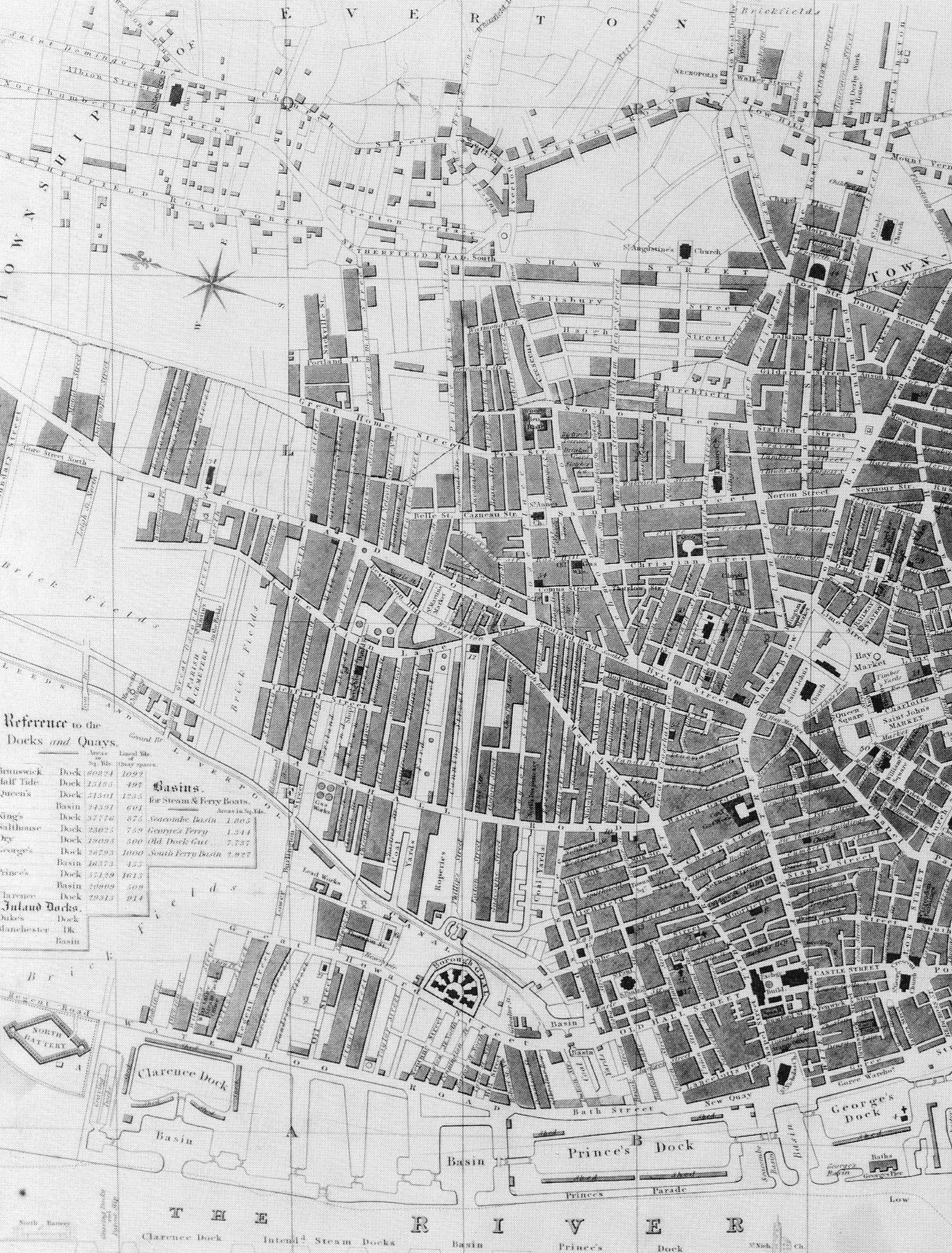




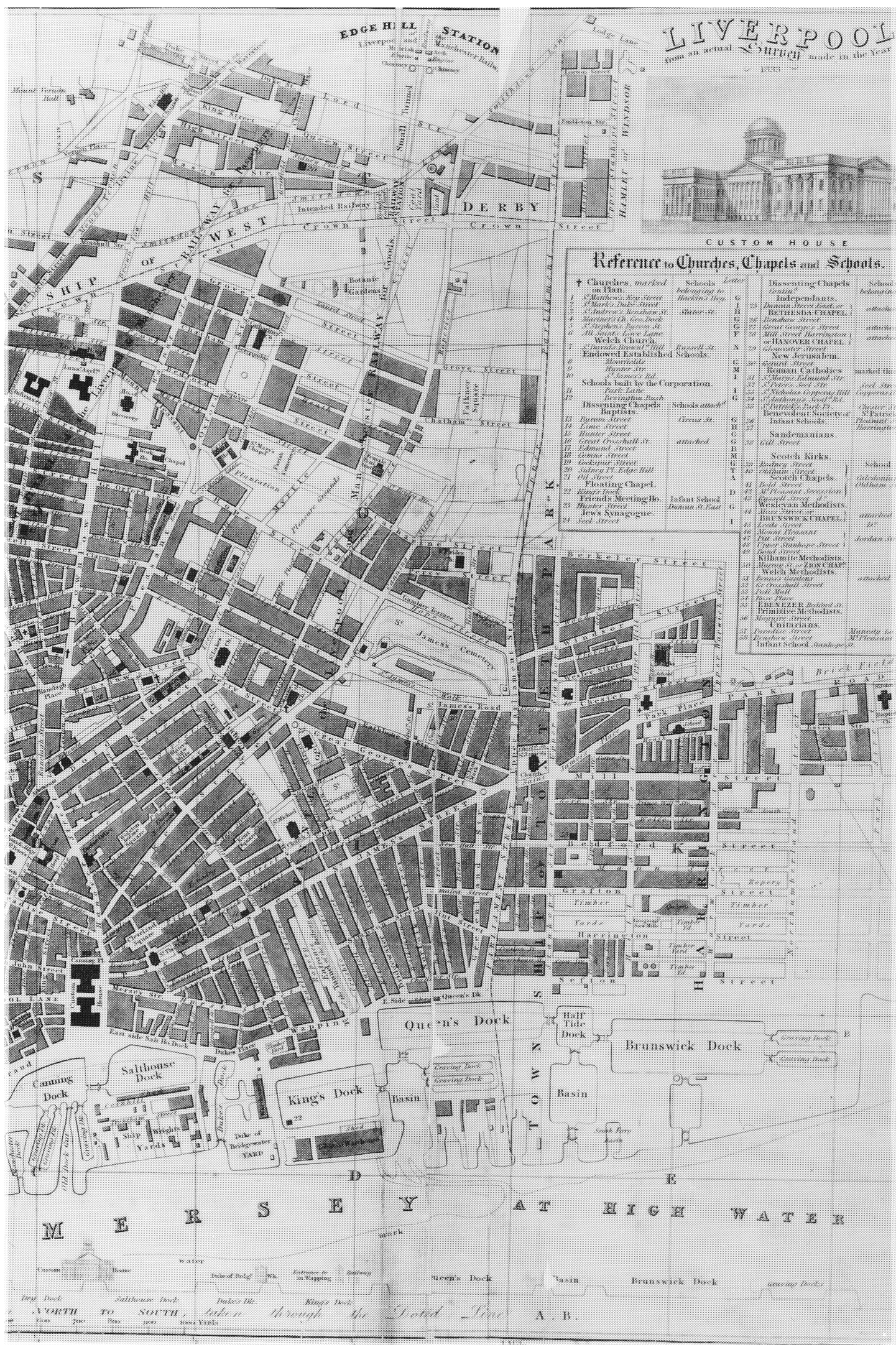




\section{VICTORIAN LITERATURE AND CULTURE}

Volume 38, Number 2 


\section{ADVISORY BOARD}

James Eli Adams

Richard D. Altick

Isobel Armstrong

Nancy Armstrong

Nina Auerbach

Houston A. Baker, Jr.

Tim Barringer

Gillian Beer

Harold Bloom

Patrick Brantlinger

Susan P. Casteras

Ed Cohen

Thomas J. Collins

Dwight Culler

Regenia Gagnier

Sandra M. Gilbert

Margaret Homans

Gerhard Joseph

Joseph Kestner

U. C. Knoepflmacher

Robert Langbaum

George Levine

Tricia Lootens

Jane Marcus

Jerome J. McGann
Michael Meredith

Dorothy Mermin

J. Hillis Miller

Lynda Nead

Linda Nochlin

Jeff Nunokawa

Mary Poovey

Robert Preyer

Yopie Prins

Harriet Ritvo

Hilary M. Schor

E. Warwick Slinn

Ruth A. Solie

Richard Stein

Margaret Stetz

Herbert Sussman

John Sutherland

G. B. Tennyson

Michael Timko

Herbert Tucker

Martha Vicinus

Malcolm Warner

Michael Wheeler

Carolyn Williams 


\title{
VICTORIAN LITERATURE AND CULTURE
}

Volume 38, Number 2

EDITORS

\section{JOHN MAYNARD ADRIENNE MUNICH}

\begin{abstract}
Associate Editor: Sandra Donaldson
Managing Editor: Abigail Burnham Bloom

Assistant Editors: Genevieve Gage-Hawes, Tamar Heller,

Carmen R. Henkel, Beth Kramer, Tara McGann, Karen Odden,

Karen Schultz, Amanda Trejbrowski, and Stephanie Wardach
\end{abstract}

Editor for Reviews: Winifred Hughes

Associate Editor for Reviews: Annette T. Snape

Pictures Editor: Morna O’Neill

Editor for Topics: Maria Jerinic

Special Effects Editor: Jeffrey Spear

Editor for Victorians Live: Herbert Sussman

CAMBRIDGE UNIVERSITY PRESS

2010 
VICTORIAN LITERATURE AND CULTURE is a publication of Cambridge University Press. It is published through the generous support of New York University, the State University of New York at Stony Brook, and the University of North Dakota. The editors gratefully acknowledge our indebtedness to our editorial assistants Leslie Barnes and Margaret Wright.

Editorial correspondence and submissions in hard copy can be addressed to either editor: Adrienne Munich, Department of English, SUNY/Stony Brook, Stony Brook, NY 11794 (631 632 7414; fax: 631632 1303);

John Maynard, Department of English, NYU, 13 University Pl., Rm. 529, N.Y., NY 10003

(212 998 8835; fax: 212995 4019).

Submissions by email may be sent to either editor in Word or RTF format:

Adrienne Munich (Adrienne.Munich@Stonybrook.edu) and John Maynard (John.Maynard@nyu.edu).

Articles should be double-spaced throughout and follow the new MLA style (with a list of Works Cited at the conclusion). Chapters of books submitted for the Works in Progress section may follow the author's chosen style in the book project.

Correspondence concerning review essays should be emailed to Winifred Hughes (winnie.spar@verizon.net).

Suggestions for reprints of Victorian materials, texts, or illustrations, and also bibliographic or other kinds of summary work should be emailed to Jeffrey Spear (Jeffrey.Spear@nyu.edu).

Ideas for Editors' Topics (groups of articles on a common subject, issue, or approach) should be raised with Maria Jerinic (mjerinic@yahoo.com).

Ideas for Victorians Live (the afterlife of the Victorians, the ways that Victorian literature and culture remain alive, continue to live in our own day) can be e-mailed to Herbert Sussman (Hlsuss@ aol.com).

Our website for contents of prior volumes and editorial information: http://www.nyu.edu/gsas/dept/english/journal/ victorian/

E-mail for general correspondence (not submission of papers): vlc.journal@nyu.edu

Publishing, Subscription, and Advertising Offices: Cambridge University Press, 32 Avenues of the Americas, New York, NY 10013-2473, USA (for the United States, Canada, and Mexico); and Cambridge University Press, The Edinburgh Building, Shaftesbury Road, Cambridge CB2 8RU, England (for U.K. and elsewhere).

Victorian Literature and Culture is published biannually in March and September. 2010 Annual institutional subscription rates (print and electronic): US \$191.00 in the U.S., Canada, and Mexico, UK $£ 115.00$ elsewhere; (electronic only) US $\$ 159.00$ in the U.S., Canada, and Mexico, UK $£ 96.00$ elsewhere; (print only) US \$178.00 in the U.S., Canada, and Mexico, UK $£ 107.00$ elsewhere. Individual rates (print only): US \$51.00 in the U.S., Canada, and Mexico; UK $£ 31.00$ elsewhere.

E-mail for orders and subscription information: journals-subscriptions@cambridge.org

The Cambridge University Press website for Victorian Literature and Culture is: http://journals.cambridge.org/vlc

(C) Cambridge University Press 2010. All rights reserved. No part of this publication may be reproduced, in any form or by any means, electronic, photocopy, or otherwise, without permission in writing from Cambridge University Press. For further information see http://us.cambridge.org/information/rights/ or http://www.cambridge.org/uk/information/rights/

All rights reserved. No part of this publication may be reproduced in any form or by any means, electronic, photocopying, or otherwise, without permission in writing from Cambridge University Press. Photocopying information for users in the U.S.A.: The Item-Fee Code for this publication (1060-1503/10 \$15.00) indicates that copying for internal or personal use beyond that permitted by Sec. 107 or 108 of the U.S. Copyright Law is authorized for users duly registered with the Copyright Clearance Center (CCC), provided that the appropriate remittance of $\$ 15.00$ is paid directly to: CCC, 222 Rosewood Drive, Danvers, MA 09123. Specific written permission must be obtained for all other copying.

Printed in the United States of America.

Postmaster: Send address changes in the U.S., Canada, and Mexico to: Victorian Literature and Culture, Journals Department, Cambridge University Press, 100 Brook Hill Drive, West Nyack, NY 10994-2133. 


\section{CONTENTS \\ VOLUME 38, NUMBER 2}

Advertising and Fiction in The Pickwick Papers

ANDY WILLIAMS

Breaking the Idol of the Marriage Plot in Yeast and Villette

TIMOTHY L. CARENS

Advanced Conservative Liberalism: Party and Principle in Trollope's

Parliamentary Novels

DAVID M. CRAIG

"Greatly Altered": The Life of Sydney Owenson's Indian Novel

CÓILÍN PARSONS

EDITORS' TOPIC: VICTORIAN COSMOPOLITANISMS

Guest Editors: Tanya Agathocleous and Jason R. Rudy

Victorian Cosmopolitanisms: Introduction

TANYA AGATHOCLEOUS AND JASON R. RUDY

Position Papers

Cosmopolitanism's Actually Existing Beyond; Toward a Victorian

Geopolitical Aesthetic

LAUREN M. E. GOODLAD

"The Country of the Plague": Anticulture and Autoethnography

in Dickens's 1850s

JAMES BUZARD

Victorian Cosmopolitanism, Interrupted

BRUCE ROBBINS

Articles

Cosmopolitanism, Feminism, and the Moving Body

JUDITH R. WALKOWITZ

Anti-Slavery Cosmopolitanism in the Black Atlantic

EDLIE WONG

vii 
Matthew Arnold and Religion's Cosmopolitan Histories

DAVID KURNICK

Medical Cosmopolitanism: Middlemarch, Cholera, and the Pathologies of English Masculinity

MARY WILSON CARPENTER

Reluctant Cosmopolitanism in Dickens's Great Expectations

JOHN MCBRATNEY

Rule Bohemia: The Cosmopolitics of Subculture in George

Du Maurier's Trilby

KIMBERLY J. STERN

The Cosmopolitan Nationalism of Sarojini Naidu, Nightingale of India

SHESHALATHA REDDY

Good Europeans and Neo-Liberal Cosmopolitans: Ethics and Politics in Late Victorian and Contemporary Cosmopolitanism

REGENIA GAGNIER

Index 


\section{ILLUSTRATIONS}

Page 428

Figure 1. "Mrs. Prowlina Pry," Engraving, from Punch 107 (27 Oct. 1894): 194. Courtesy of Johns Hopkins University.

Page 439

Figure 2. “A Facer," Engraving, from Judy, 24 Oct. 1894, 193. Courtesy of the New York Public Library.

Page 440

Figure 3. "Suggested new Empire costume!" Engraving, from Moonshine, 27 Oct. 1894, 194. Courtesy of the New York Public Library.

Page 443

Figure 4. "The Finest Stage Crowd of Recent Years: 'Votes for Women,"' Sketch, 15 May 1907, 131. Courtesy of the New York Public Library.

Page 444

Figure 5. "Maud Allan as Salome," 1908. Collection of the author.

Page 555

Figure 6. George Du Maurier, "Wistful and Sweet." Engraving for Trilby, from Harper's New Monthly Magazine 88 (Jan. 1894): 175.

Page 566

Figure 7. George Du Maurier, “A Throne in Bohemia.” Engraving for Trilby, from Harper's New Monthly Magazine 89 (Aug. 1894): 352. 